\title{
The use of taxonomic studies to the identification of wetlands weeds
}

\author{
Maryam A. Butt ${ }^{\mathrm{a} \mathrm{d}^{*} \odot}$, Muhammad Zafar ${ }^{\circledR}$, Mushtaq Ahmad ${ }^{\circledR}$, Sadaf Kayani ${ }^{\mathrm{b}}$, Saraj Bahadur ${ }^{\oplus}$, Fazal Ullah ${ }^{\circledR}$, Shazia Khatoon ${ }^{\mathrm{d}}$ \\ a Department of Plant Sciences, Quaid- i- Azam University Islamabad, Islamabad, Pakistan. ${ }^{b}$ Mohi-ud-Din Islamic University Nerian Sharif, AJK. ${ }^{\circ}$ \\ College of Forestry, Hainan University Haikou 570228, China. ${ }^{d}$ Department of Botany, University of Kotli Azad Jammu and Kashmir. ${ }^{e}$ CAS Key \\ Laboratory of Mountain Ecological Restoration and Bioresource Utilization and Ecological Restoration, Biodiversity Conservation Key Laboratory \\ of Sichuan Province, Chengdu Institute of Biology, Chinese Academy of Science, China.
}

Abstract: Background: Palyno-anatomy of wetland species belonging to 10 families was studied in the present research work through light microscopy (LM) and scanning electron microscopy (SEM), to find valuable taxonomic characters.

Objective: This study aims to provide baseline information of the micro-morphological characters of 24 wetland species which will be helpful for further identification of wetlands weeds flora.

Methods: 24 weeds were collected from different wetlands of Azad Kashmir. Taxonomic tools like light microscopic and scanning electron microscopic techniques are used for the proper identification of wetland weeds.

Results: The results show diversity among the qualitative and quantitative characters of epidermal cells, stomata, trichomes, and stomatal pore on both leaf surfaces. In accordance with these variations, a taxonomic key was prepared by using these characters for the identification and differentiation of wetland plant species. In pollen evaluations, variations were observed among exine sculpturing, the number of pores, exine thickness, and diameter of pollens.

Conclusions: Based on our findings it will be helpful for the taxonomist to identify other wetland species by using these micro-morphological characters. This study also indicates that at different taxonomic levels, LM and SEM of pollen and epidermal morphology is explanatory and significant to identify plants up to the species level.

Keywords: Wetland weeds, Taxonomy, Stomata, Trichomes, Pollens, Exine ornamentation

Journal Information:

ISSN - 2675-9462

Website: http://awsjournal.org

Journal of the Brazilian Weed

Science Society

How to cite: Butt AK, Zafar $M$ Ahmad M, Kayani S, Bahadur S, Ullah F, Khatoon S. The use of taxonomic studies to the identification of wetlands weeds. Adv Weed Sci. 2020;39:e222645. https://doi.org/10.51694/AdvWeedSci/2021;39:000013

Approved by:

Editor in Chief: Leonardo d'Antonino

Conflict of interest: The authors declare that they have no known competing for financial interests or personal relationships that could have appeared to influence the work reported in this paper.

Received: April 12, 2019

Approved: April 29, 2019

* Corresponding author: botanist.maryam@outlook.com

\section{(c) (4)}

This is an open-access article distributed under the terms of the Creative Commons Attribution License, which permits unrestricted use, distribution, and reproduction in any medium, provided that the original author and source are credited.

Copyright: 2021

\section{Introduction}

The term anatomy is used to study the internal structure of plants. The study of anatomical characters has much importance in different types of systematic research work. The foliar epidermal studies are essential for delimitation, classification, and for arranging the evolutionary and phylogenetic difficulties which include interrelationship among the plant species (Munir et al., 2011; Pereira et al., 2017; Ahmad et al., 2017). The foliar epidermal anatomy of plants is valuable in studying systematics and phylogenetic relationships of the taxa and it plays a significant role in the field of cytology (Bunawan et al., 2011; Khan et al., 2017; Lersten, Curtis, 1992). The epidermis contains numerous types of functionally specialized cells and plays an important role in controlling water loss, defense against intense sunlight and wind, regulate gaseous exchange, photosynthesis, and attract the pollinators, respiration, transpiration, flexibility, and mechanical strength. According to (Wetzel et al., 2017) to study systematics and characterization within subfamilies and tribes, foliar epidermal features are very important.

The epidermis is the most external cellular layer whose characters are under gene control and is influenced to some extend by environmental factor (El-Ghamery et al., 2017). Bio systematically, foliar epidermal characters such as size and shape of stomatal complex, their placement, structural specialties of epidermal cell walls, and typical forms of trichomes help in the identification of many plant families (Chaudhari et al., 2014; Özdemir et al., 2016). The previous literature shows that leaf epidermal features play a key role in systematic botany similar to the use of modern methods such as the search for a pattern of evolution, and biochemical composition (Uka et al., 2014; Waly, 2013). Stomatal characteristics include the arrangement and distribution of stomata, shape of stomata, subsidiary cells, stomatal edge and guard cells, and stomatal size (Wang et al., 2015).

Wetland is a land that is either temporary or permanently covered with water and the basic factor that differentiates wetland from other landforms is the vegetation of wetland plants (Keddy 2010). Wetland vegetation is an important part of the world's flora (Sardar, 2008). Previous studies show that much work has been done on family Pontederiaceae (Arber, 2010). Some work is also done regarding palynology on family Haloragaceae (Kubitzki, 2007), family Mimosaceae, and Nymphaceae (Bhunia, Mondal, 2012). Pollen studies of the Lemnaceae family were studied by (Hesse, 2006; 
Alwadie, 2008), family Potamogetonaceae (El-Amier, 2015), Typhaceae family (Arenas, Scarpa, 2003), Podostemaceae (de Sá-Haiad et al., 2010), and Eriocaulaceae family (Borges et al., 2009).

Wetland plants are remarkable plants due to their moist habitat in which they live. Wetland plants include species of different habitats, as emerged or submerged, true aquatics which are free-floating. Plants that are growing between water and land are considered aquatic plants (Özdemir et al., 2016; Santos et al., 2004). The present research work is done in several rivers, lakes, reservoirs, tanks, waterfalls, ponds, ditches, and puddles. Water bodies provide a constant habitat; therefore, the anatomical structures of wetland plants are less different than those of xerophytes and mesophytes. Pakistan is a fairly large country gifted with a variety of climates, ecological zones, and topographical regions. Particularly the region of Azad Kashmir, which is bestowed by plant diversity and natural water resources provides a great habitat for wetland flora. In terms of wetland, Azad Kashmir flora is less explored and the location of the research area is near the agricultural field because this area is lush green. In creating ecological balance in a crop system weeds play a sufficient role by supporting different life forms. Amaranthus viridis, Cynodon dactylon, Phragmites australis and Phyla nodiflora was reported as important weeds of cotton crop (Memoni et al., 2014). Memoni et al., 2013 illustrated the Cynodon sp., Phragmites sp., Polypogon sp., and Ranunculus spp. as weed flora of wheat crop. Similarly, Achyranthes aspera is a common weed in sugarcane (Saccharum officinarum L.) (Jogil et al., 2019) and on chickpea fields, Plantago lanceolata was documented as a major weed (Hassan et al., 2010). The correct identification of species is determinant for developing any weed management program according to its different ecological aspects. The taxonomic studies are preliminary research towards the use of identification and classification of wetlands weeds of the study area, which could be in the same way useful for weed scientists as well as for botanists. Thus, the present study aims to provide a baseline of the palyno-anatomical characters of wetland weed species through taxonomic approaches for the proper identification.

\section{Material and methods}

\subsection{Plant material}

A total of 24 weeds belonging to 10 families was collected from different wetlands of Azad Kashmir. Azad Kashmir is situated with GPS coordinates of $33^{\otimes} 30^{\prime} 46.76^{\prime \prime}$ North and $73^{\otimes} 45^{\prime \prime} 20.07$ " East with an area of $13,297 \mathrm{~km}^{2}$ (Rafique et al., 2013). Plants samples were collected from different wetlands of Azad Kashmir. These specimens were identified and confirmed with the help of Flora of Pakistan and available literature (Ali, 1980; Nasir, Ali, 1970). A voucher number was given to each specimen collected. Collected specimens were pressed in a presser, dried in newspapers, identified, and mounted on herbarium sheets. The identified voucher specimens were deposited in the herbarium of Pakistan Quaid-i-Azam University Islamabad. The list of plants their altitude and distribution are presented in Table 1.

\begin{tabular}{|c|c|c|c|c|c|c|}
\hline Sr.No & Plant species & Collector & Locality & Distract/Province & $\begin{array}{l}\text { Altitude } \\
\text { (meter) }\end{array}$ & $\begin{array}{l}\text { Voucher } \\
\text { Number }\end{array}$ \\
\hline 1. & $\begin{array}{l}\text { Achyranthus osperoL. } \\
\text { (Amaranthaceae) }\end{array}$ & $\begin{array}{c}\text { Maryam Akram Butt, Essam } \\
\text { Akram Butt }\end{array}$ & Mangla lake & Mirpur/Azad Kashmir & 458 & MA-71 \\
\hline 2. & $\begin{array}{c}\text { Alismo plantago-aquatica L. } \\
\text { (Alismataceae) }\end{array}$ & Maryam Akram Butt, Tariq Butt & Sehnsa wetland & Kotli/Azad Kashmir & 679 & MA-60 \\
\hline 3. & $\begin{array}{c}\text { Alternathera sessilis (L.) DC. } \\
\text { (Amaranthaceae) }\end{array}$ & Maryam Akram Butt, Tariq Butt & Sehnsa wetland & Kotli/Azad Kashmir & 679 & MA-61 \\
\hline 4. & $\begin{array}{l}\text { Amaranthus spinosus L. } \\
\text { (Amaranthaceae) }\end{array}$ & $\begin{array}{c}\text { Maryam Akram Butt, Essam } \\
\text { Akram Butt }\end{array}$ & Mangla lake & Mirpur/Azad Kashmir & 458 & MA-66 \\
\hline 5. & $\begin{array}{l}\text { Amoranthus viridis } \mathrm{L} . \\
\text { (Amaranthaceae) }\end{array}$ & $\begin{array}{c}\text { Maryam Akram Butt, Essam } \\
\text { Akram Butt }\end{array}$ & Mangla lake & Mirpur/Azad Kashmir & 458 & MA-87 \\
\hline 6. & $\begin{array}{c}\text { Arundo donax L. } \\
\text { (Poaceae) }\end{array}$ & Maryam Akram Butt, Tariq Butt & Sehnsa wetland & Kotli/Azad Kashmir & 679 & MA-68 \\
\hline 7. & $\begin{array}{l}\text { Bocopa monnieri (L.) Wettst. } \\
\text { (Plantaginaceae) }\end{array}$ & $\begin{array}{c}\text { Maryam Akram Butt, Essam } \\
\text { Akram Butt }\end{array}$ & Mangla lake & Mirpur/Azad Kashmir & 458 & MA-59 \\
\hline 8. & $\begin{array}{c}\text { Brachioria reptans (L.) } \\
\text { C.A.Gardner \& C.E.Hubb. } \\
\text { (Poaceae) }\end{array}$ & Maryam Akram Butt, Tariq Butt & Sehnsa wetland & Kotli/Azad Kashmir & 679 & MA-30 \\
\hline 9. & $\begin{array}{c}\text { Cynodon dactylon (L.) Pers. } \\
\text { (Poaceae) }\end{array}$ & Maryam Akram Butt, Tariq Butt & Sehnsa wetland & Kotli/Azad Kashmir & 679 & MA-29 \\
\hline 10. & $\begin{array}{l}\text { Dichanthium annulatum } \\
\text { (Forssk.) Stapf (Poaceae) }\end{array}$ & $\begin{array}{c}\text { Maryam Akram Butt, Tariq } \\
\text { Butt }\end{array}$ & $\begin{array}{l}\text { Sehnsa } \\
\text { wetland }\end{array}$ & Kotli/Azad Kashmir & 679 & MA-12 \\
\hline
\end{tabular}




\begin{tabular}{|c|c|c|c|c|c|c|}
\hline 11. & $\begin{array}{l}\text { Echinochloo colono (L.) Link } \\
\text { (Poaceae) }\end{array}$ & Maryam Akram Butt, Tariq Butt & Sehnsa wetland & Kotli/Azad Kashmir & 679 & MA-63 \\
\hline 12. & $\begin{array}{c}\text { Persicario moculoso S.F. Gay, } \\
\text { Nat.(Polygonaceae) }\end{array}$ & Maryam Akram Butt, Tariq Butt & Sehnsa wetland & Kotli/Azad Kashmir & 679 & MA-29 \\
\hline 13. & $\begin{array}{c}\text { Phragmites australis (Cav.) Trin. } \\
\text { ex Steud. (Poaceae) }\end{array}$ & Maryam Akram Butt, Tariq Butt & Sehnsa wetland & Kotli/Azad Kashmir & 679 & MA-49 \\
\hline 14. & $\begin{array}{c}\text { Phrogmites karko (Retz.) Trin. } \\
\text { Ex Steud. (Poaceae) }\end{array}$ & Maryam Akram Butt, Tariq Butt & Sehnsa wetland & Kotli/Azad Kashmir & 679 & MA-76 \\
\hline 15. & $\begin{array}{c}\text { Phyla nodiflora (L.) Greene } \\
\text { (Verbenaceae) }\end{array}$ & $\begin{array}{c}\text { Maryam Akram Butt, Essam } \\
\text { Akram Butt }\end{array}$ & Mangla lake & Mirpur/Azad Kashmir & 458 & MA-79 \\
\hline 16. & $\begin{array}{l}\text { Plantago lanceolato L. } \\
\text { (Plantaginaceae) }\end{array}$ & $\begin{array}{l}\text { Maryam Akram Butt, Tariq Butt, } \\
\text { Usman Tariq, Essam Akram Butt }\end{array}$ & Banjosa lake & Poonch/Azad Kashmir & 1,981 & MA-55 \\
\hline 17. & $\begin{array}{l}\text { Plantogo major L. } \\
\text { (Plantaginaceae) }\end{array}$ & $\begin{array}{c}\text { Maryam Akram Butt, Tariq Butt, } \\
\text { Usman Tariq, Essam Akram } \\
\text { Butt }\end{array}$ & Banjosa lake & Poonch/Azad Kashmir & 1,981 & MA-99 \\
\hline 18. & $\begin{array}{c}\text { Polypogon monspeliensis (L.) } \\
\text { Desf. (Poaceae) }\end{array}$ & Maryam Akram Butt, Tariq Butt & Sehnsa wetland & Kotli/Azad Kashmir & 679 & MA-80 \\
\hline 19. & $\begin{array}{c}\text { Ronunculus repens L. } \\
\text { (Ranunculaceae) }\end{array}$ & Maryam Akram Butt, Tariq Butt & Sehnsa wetland & Kotli/Azad Kashmir & 679 & MA-78 \\
\hline 20. & $\begin{array}{l}\text { Ranunculus scleratus L. } \\
\text { (Ranunculaceae) }\end{array}$ & Maryam Akram Butt, Tariq Butt & Sehnsa wetland & Kotli/Azad Kashmir & 679 & MA-45 \\
\hline 21. & $\begin{array}{l}\text { Solvia plebeia R.Br. } \\
\text { (Lamiaceae) }\end{array}$ & $\begin{array}{c}\text { Maryam Akram Butt, Essam } \\
\text { Akram Butt }\end{array}$ & Mangla lake & Mirpur/Azad Kashmir & 458 & MA-89 \\
\hline 22. & $\begin{array}{c}\text { Typho ongustifolia L. } \\
\text { (Typhaceae) }\end{array}$ & Maryam Akram Butt, Tariq Butt & Sehnsa wetland & Kotli/Azad Kashmir & 679 & MA-12 \\
\hline 23. & $\begin{array}{l}\text { Verboscum thapsus L. } \\
\text { (Scrophulariaceae) }\end{array}$ & Maryam Akram Butt & Mangla lake & Mirpur/Azad Kashmir & 458 & MA-77 \\
\hline 24. & $\begin{array}{l}\text { Veronica anagallis-aquatica L. } \\
\text { (Plantaginaceae) }\end{array}$ & Maryam Akram Butt & Mangla lake & Mirpur/Azad Kashmir & 458 & MA-88 \\
\hline
\end{tabular}

\subsection{Palynological studies}

In the present study 13 species of wetland flora have been studied regarding their pollen morphology (Table 4). For pollen analysis, the method proposed by Borsch (1998) has been followed. In which anthers from the flowers were separated and put on a glass slide, and then added 1-2 drops of Acetic acid. They were crushed with the help of a glass rod, mounted with glycerin jelly for staining on a glass slide. Several pollen micro-morphological characters were measured with the help of a Leica Dialup 20 microscope. For Scanning Electron Micrographs, the pollen grains in a droplet of water were suspended and were transferred directly to double side tape affixed to a stub with a fine pipette and gold-coated sputter to $150 \mathrm{~A}$. The pollen specimens inserted on slides were observed and photographed with a Jeol JSM-T200 SEM at $15 \mathrm{kV}$.

\subsection{Leaf epidermal anatomy}

For leaf anatomy, we followed the modified techniques of (Nazir et al., 2013). Leaves were collected from mature plants for anatomical study. Leaf samples were taken in the test tube and dip in lactic acid $70 \%$ and $30 \%$ nitric acid, boiled for 2 minutes. The leaves were poured into Petri dishes; epidermis was isolated through lax camel brush and mounted on glass slides. Both upper and lower epidermis surfaces were separated. Separated epidermis transparent samples were washed twice with water and after that with lactic acid for 5 to 6 seconds. Afterward, the samples were covered with coverslips. The corner of coverslips on glass slides was coated with transparent nail polish, for making permanent slides. Six samples of both adaxial and abaxial surfaces were made for each species. The samples were studied under the light microscope (Model: XSP-45 LCD) for different epidermis parameters. Under the microscope, we observed quantitative and qualitative characters. Quantitative characters include epidermal cell length (L) and width (W), stomata length (L) and width (W), stomatal pore length (L) and width (W), number of epidermal cells, number of stomata, width, and length of the cell wall. The qualitative characters included types of stomata, shape of epidermal cell, shape of anticlinal wall, shape of subsidiary cells, and shape of trichomes.

\subsection{Statistical analysis}

The qualitative and quantitative features are summarized in (Tables 2 and 3), respectively. Quantitative features are represented by minimum - maximum $=$ mean \pm standard error (for example: $27.7-105=(85.2 \pm 10.8)$. Five readings of each character were noted for each adaxial and abaxial surface. The quantitative data were noted and processed using SPSS 16.0 software to determining minimum maximum, mean and standard error; these data are very helpful in the identification of species and the nature of different epidermis characters. These indices give us information about the length and width of stomata, epidermal cells, subsidiary cells, stomatal pore, trichomes, and percentages of the stomatal complex. 
Table 2 - Qualitative characters, foliar epidermal anatomy of wetland flora of Azad Kashmir.

\begin{tabular}{|c|c|c|c|c|c|c|c|c|c|c|}
\hline \multirow[t]{2}{*}{ Plant species } & \multicolumn{2}{|c|}{ Epidermal cells shape } & \multicolumn{2}{|c|}{ Stomata } & \multicolumn{2}{|c|}{ Type of stomata } & \multicolumn{2}{|c|}{$\begin{array}{l}\text { Trichome/ } \\
\text { Glands }\end{array}$} & \multicolumn{2}{|c|}{ Trichome type } \\
\hline & $\mathrm{Ad}^{*}$ & $A b^{* *}$ & $\mathrm{Ad}^{*}$ & $A b^{* *}$ & $\mathrm{Ad}^{*}$ & $A b^{* *}$ & $\operatorname{Ad}^{*}$ & $A b^{* *}$ & $\operatorname{Ad}^{*}$ & $A b^{* *}$ \\
\hline $\begin{array}{l}\text { Alternathera sessilis } \\
\text { (L.) DC. }\end{array}$ & Irregular & Irregular & $P$ & $P$ & Anomocytic & Anomocytic & $A$ & $P$ & -- & $\begin{array}{l}\text { Multicellular } \\
\text { capitate }\end{array}$ \\
\hline $\begin{array}{l}\text { Achyranthus aspera } \\
\text { L. }\end{array}$ & Elongated & Irregular & $\mathrm{P}$ & $P$ & anomocytic & Paracytic & $P$ & $P$ & $\begin{array}{l}\text { Attenuate and } \\
\text { bulbous base }\end{array}$ & $\begin{array}{l}\text { Attenuate and } \\
\text { bulbous base }\end{array}$ \\
\hline $\begin{array}{l}\text { Amaranthus spinosus } \\
\text { L. }\end{array}$ & Irregular & Irregular & $P$ & $P$ & Anomocytic & Anomocytic & A & A & -- & -- \\
\hline Amaranthus viridis $L$. & Irregular & Irregular & $\mathrm{P}$ & $\mathrm{P}$ & $\begin{array}{l}\text { Anisocytic } \\
\text { Anomocyic }\end{array}$ & $\begin{array}{l}\text { Anisocytic } \\
\text { Anomocyic }\end{array}$ & A & A & -- & -- \\
\hline $\begin{array}{l}\text { Alisma } \\
\text { plantago-aquatica L. }\end{array}$ & Polygonal & Polygonal & $P$ & $\mathrm{P}$ & Anomocyic & Anomocyic & A & A & -- & -- \\
\hline Plantago lanceolata L. & Isodiametric & Isodiametric & $P$ & $\mathrm{P}$ & Anomocytic & Anomocytic & $P$ & $P$ & -- & -- \\
\hline Plantago major L. & Polygonal & Polygonal & $\mathrm{P}$ & $P$ & Anisocytic & Anisocytic & $p$ & $P$ & Barrel-shaped & Barrel-shaped \\
\hline $\begin{array}{l}\text { Bacopa monnieri (L.) } \\
\text { Wettst. }\end{array}$ & Irregular & Polygonal & $\mathrm{P}$ & $\mathrm{P}$ & Diacytic & Anisocytic & $P$ & $P$ & $\begin{array}{l}\text { Peltate / } \\
\text { Glandular } \\
\text { sessile } \\
\text { trichomes }\end{array}$ & Peltate \\
\hline
\end{tabular}

Veronica

anagallis-aquatica L

Irregular

Irregular

P P Anomocytic Anomocytic

Unicellular

Ranunculus

scleratus L.

Wavy

Wavy

P P Paracytic

Paracytic

non-glandular

Ranunculus repens L. Irregular

Irregular

P P Paracytic

Paracytic

Unicellular

Phyla nodiflora (L)

Greene

Isodiametric Isodiametric $P$ P $\quad$ Anisocytic Anisocytic

Verbascum thapsus L.

Irregular

Irregular$$
P
$$

Anisocytic

Salvia plebeia R.Br.

Irregular

Irregular

A

Typha angustifolia L.

Rounded

Rounded

Arundo donax $\mathrm{L}$

Irregular

Irregular

$P$
$P$

Paracytic

Polypogon

monspeliensis (L.)

Desf.

Phragmites australis

(Cav.) Trin. ex Steud.

Elongated

Elongated

Irregular

Irregular

P

Paracytic

Paracytic

Phragmites karka

(Retz.) Trin. Ex Steud.

Cynodon dactylon (L.)

Pers.

Brachiaria reptans

(L.) C.A.Gardner \&

C.E.Hubb.

Echinochloa colona

(L.) Link

Dichanthium

annulatum (Forssk.)

Stapf

Persicaria maculosa S.F. Gay, Nat.

\section{Irregular}

Irregular

Irregular

Irregular

$$
\text { Irregular }
$$

Irregular

Irregular

Iregular

Irregular

Irregular

Tetragonal Tetragonal
Irregular
Paracytic

Paracytic

Paracytic

Paracytic

Paracytic

Paracytic

Paracytic

Paracytic

P

P

P

P P Anomocytic Anomocytic

\section{Non-glandular}

Non-glandular

\section{A $\quad A$}

P P

\section{Stellate \\ Simple}

Stellate

Multicellular Multicellular Non-glandular Non-glandular

\section{Prickles}

Prickles

Ad*: Adaxial; Ab: Abaxial; P: Present; A: Absent 


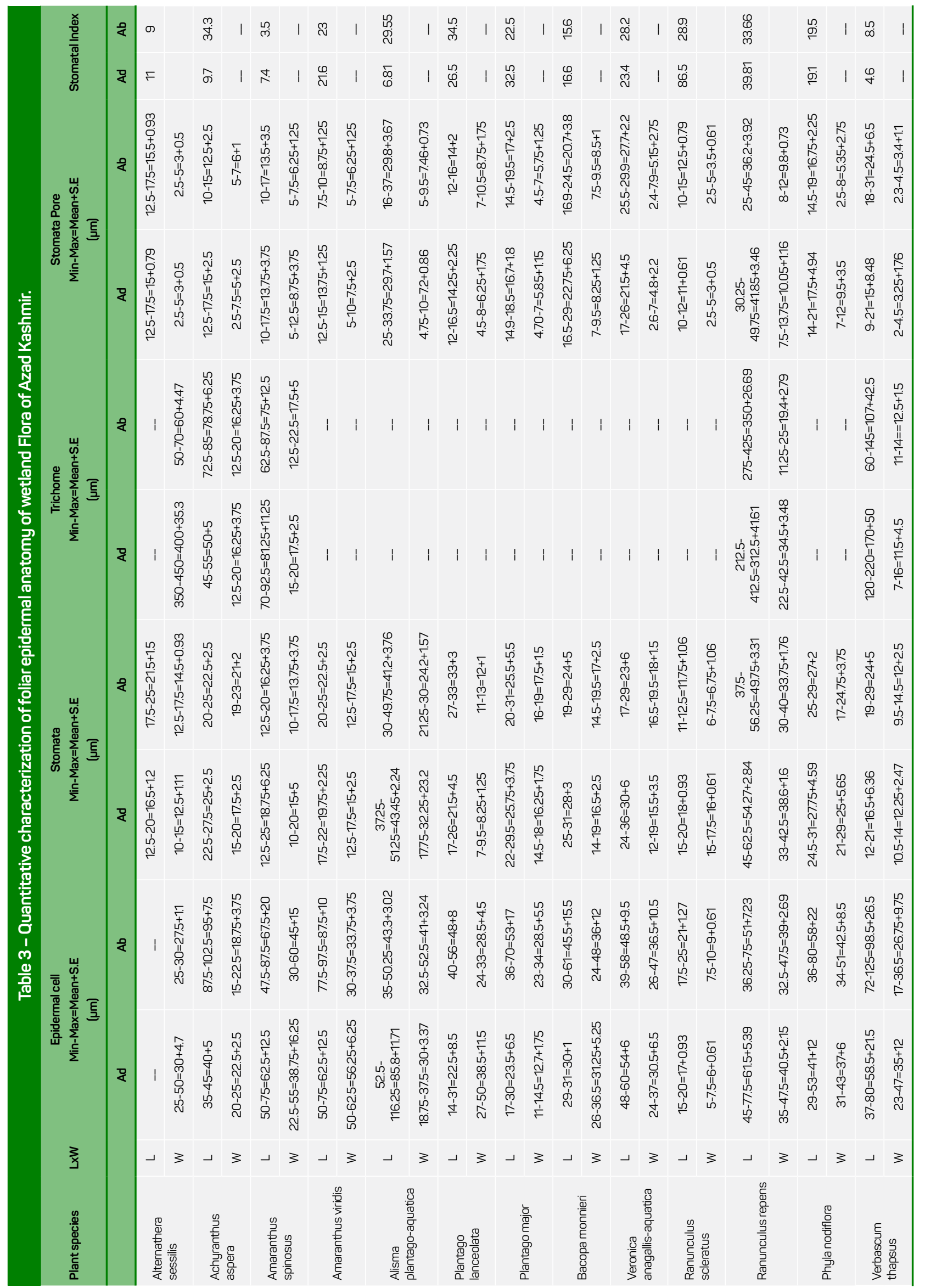




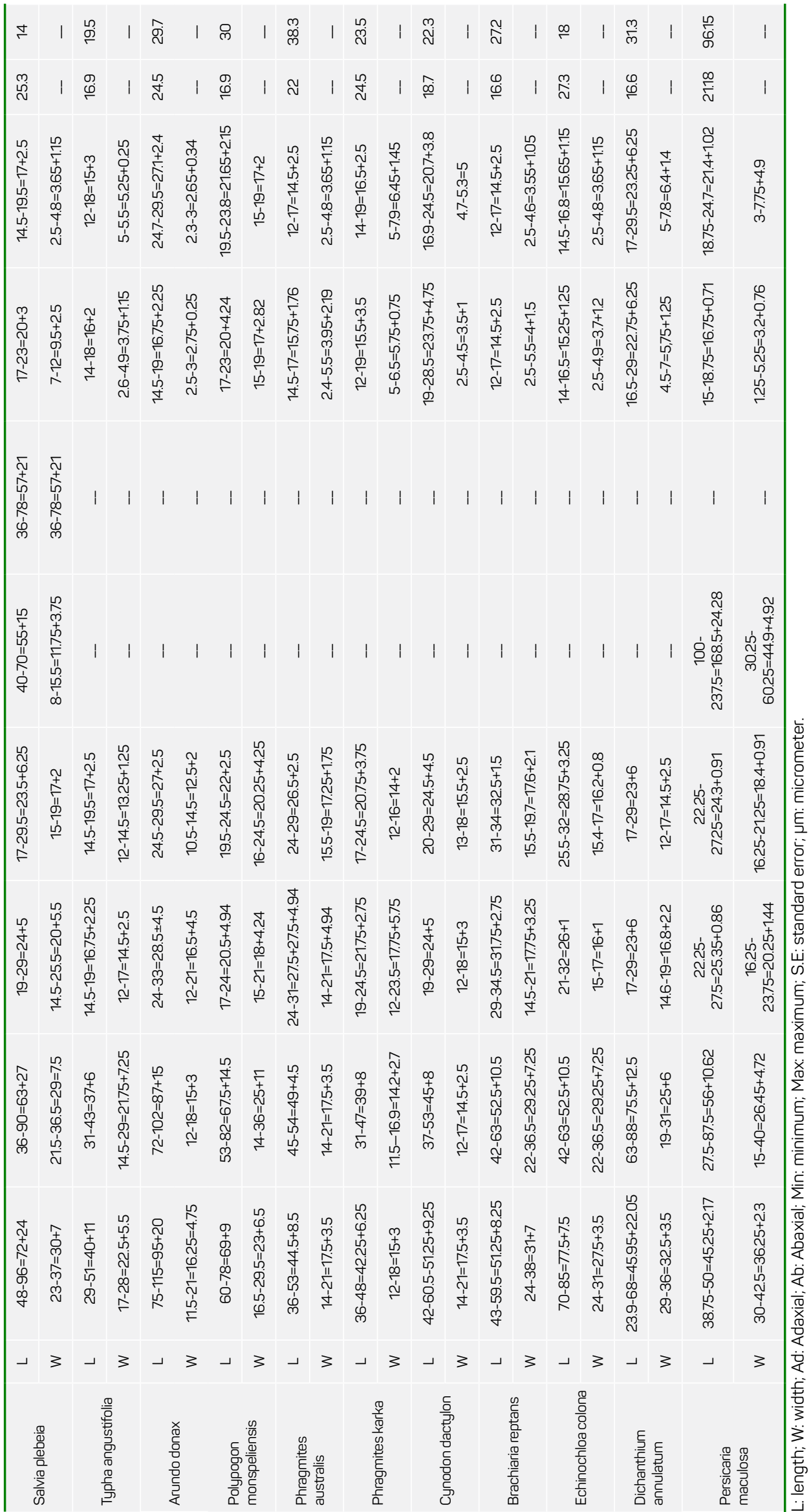




\begin{tabular}{|c|c|c|c|c|c|c|}
\hline Plant name & $\begin{array}{l}\text { Polar diameter } \\
(\mu \mathrm{m})\end{array}$ & $\begin{array}{l}\text { Equatorial diameter } \\
\qquad(\mu \mathrm{m})\end{array}$ & $\begin{array}{c}\text { P/E ratio } \\
\text { (Polar axis/ } \\
\text { equatorial axis) }\end{array}$ & $\begin{array}{c}\text { Exine } \\
\text { thickness } \\
\qquad(\mu \mathrm{m})\end{array}$ & $\begin{array}{l}\text { No. of } \\
\text { Pores }\end{array}$ & $\begin{array}{c}\text { Exine } \\
\text { Ornamentation }\end{array}$ \\
\hline $\begin{array}{l}\text { Achyranthus asperal. } \\
\text { (Amaranthaceae) }\end{array}$ & $7(8.2 \pm 0.3) 9.1$ & $6(6.9 \pm 0.8) 10.5$ & 1.05 & 0.8 & 36 & $\begin{array}{l}\text { Psilate to } \\
\text { scabrate }\end{array}$ \\
\hline $\begin{array}{l}\text { Alisma plantago-aquatica L. } \\
\text { (Alismataceae) }\end{array}$ & $17.2(18.9 \pm 1.3) 23.5$ & $18.9(22.1 \pm 1.1) 24$ & 2.20 & 0.9 & - & Psilate \\
\hline $\begin{array}{l}\text { Alternathera sessilis (L.) DC. } \\
\text { (Amaranthaceae) }\end{array}$ & $14(18.25 \pm 1.2) 22.5$ & $15(18.6 \pm 1.0) 22.5$ & 1.00 & 0.8 & 15 & Microechinate \\
\hline $\begin{array}{l}\text { Amaranthus spinosus L. } \\
\text { (Amaranthaceae) }\end{array}$ & $8(9.7 \pm 0.3) 11.1$ & 8.3(9.4ะ0.2)9.9 & 0.90 & 0.7 & 24 & Psilate \\
\hline $\begin{array}{l}\text { Amaranthus viridis L. } \\
\text { (Amaranthaceae) }\end{array}$ & $5.6(6.6 \pm 0.2) 7.8$ & $6.6(7.7 \pm 0.9) 9.2$ & 0.91 & 0.8 & 16 & Microechinate \\
\hline $\begin{array}{l}\text { Bacopa monnieri (L.) Wettst. } \\
\text { (Plantaginaceae) }\end{array}$ & $20(22.5 \pm 1.0) 25.0$ & $22.5(26.25 \pm 1.3) 30$ & 0.85 & 1.635 & - & Psilate \\
\hline $\begin{array}{l}\text { Cynodon dactylon (L.) Pers. } \\
\text { (Poaceae) }\end{array}$ & $21.4(24.5 \pm 0.1) 26.5$ & $13.1(15.4 \pm 0.4) 22.5$ & 1.51 & 1.21 & - & Psilate \\
\hline $\begin{array}{l}\text { Plantago lanceolata L. } \\
\text { (Plantaginaceae) }\end{array}$ & $21.5(23.6 \pm 0.1) 24.0$ & $22.9(25.1 \pm 0.12) 26$ & 0.97 & 2.5 & - & Psilate \\
\hline Plantago major L. & $18.9(22.1 \pm 0.17) 27.4$ & $14.7(19 \pm 0.2) 23.5$ & 1.04 & 1.9 & 8 & Granulate \\
\hline $\begin{array}{l}\text { Ranunculus repens L. } \\
\text { (Ranunculaceae) }\end{array}$ & $25.5(30.29 \pm 0.6) 32.75$ & $25(32.5 \pm 0.4) 31$ & 0.90 & 2.2 & - & Scabrate \\
\hline $\begin{array}{l}\text { Ranunculus scleratus L. } \\
\text { (Ranunculaceae) }\end{array}$ & $22.6(19.4 \pm 0.6) 16.0$ & $16.5(14.2 \pm 0.7) 10.1$ & 1.40 & 1.00 & - & $\begin{array}{l}\text { Psilate to } \\
\text { scabrate }\end{array}$ \\
\hline Typha latifolia L. & $22.98(24.9 \pm 1.5) 28.9$ & $26(31.2 \pm 1.4) 33.2$ & 0.70 & 2.35 & - & $\begin{array}{l}\text { Rugulate to } \\
\text { scabrate }\end{array}$ \\
\hline $\begin{array}{l}\text { Veronica anagallis-aquatica L. } \\
\text { (Plantaginaceae) }\end{array}$ & $17.9(22.2 \pm 0.5) 25.4$ & $15.9(19.7 \pm 0.2) 23.5$ & 1.13 & 2.2 & - & Psilate \\
\hline
\end{tabular}

\subsubsection{Stomatal index}

For the stomatal index, we counted the number of stomata and epidermal cells per unit area from 5 different oculars for adaxial and abaxial surfaces.

$$
\text { S.I }=\text { S/S+E (100) }
$$

(In this equation $\mathrm{S} . \mathrm{I}=$ stomatal index, $\mathrm{S}=$ number of stomata per unit area, $\mathrm{E}=$ number of epidermal cell per unit area)

\section{Results and discussion}

In the present study, examination of foliar epidermis and pollens under light and scanning electron microscope variations were found in both qualitative and quantitative features. A taxonomic key was prepared by using these qualitative characters for the identification and differentiation of wetland plant species.

\subsection{Pollen micromorphology}

In this study, pollen observed are mostly psilate in sculpturing while some species have microechinate and scabrate exine sculpturing. In some species, the number of pores also varies as Achyranthes aspera L has 36 pores while Amaranthus spinosus L has 24 numbers pores in its pollen, Amaranthus viridis L has 16 pores Alternanthera sessilis (L.)
R.Br. ex DC has 15 pores and Plantago major L has 8 pores. In the species of family Amaranthaceae, spheroidal or sub-spheroidal types of pollens were observed, in species of family Ranunculaceae prolate and sub spheroidal types were observed, in family Plantaginaceae spheroidal types of pollens were found (Figure 5). The maximum polar to equatorial ratio was observed in Alisma plantago-aquatica L. which is 2.2 followed by Cynodon dactylon (L.) Pers. 1.51, $V$. anagallis-aquatica 1.13 . The thickest exine is observed in Plantago lanceolata L. 2.5 Typha latifolia L. 2.35; Ranunculus repens L. 2.2 and $V$. anagallis-aquatica 2.2. The highest diameter in the polar view is found in $R$. repens is 30.29 $\mu \mathrm{m}, \mathrm{T}$. latifolia is $24.9 \mu \mathrm{m}$ and $C$. dactylon is $24.5 \mu \mathrm{m}$.

Variations are found in pollen micro-morphological characters including the shape of pollens, size of pollens, exine sculpturing, etc. Pollen morphology has been studied previously by (Perveen, Qaiser, 2012; Hussain et al., 2018) in which they reported that exine sculpturing of the Amaranthaceae family was scabrate to psilate, while in our study $A$. sessilis have micro-echinate exine ornamentation. Similarly, exine of T. latifolia has Rugulate to scabrate sculpturing confirmed the findings of (Bahadur et al., 2018). The pollen micro-morphology also provides delimitation of the species within the genus of the family (Dönmez et al., 2008). 
Exine of the pollen was the basic character for differentiation between the species of different families. The exine is often micro-reticulate scabrate and psilate in this study which is a taxonomically significant feature examined under SEM. Similarly, Butt et al. (2018), Kosenko (1999), Sufyan et al. (2018), Ullah et al. (2018), investigated pollen of various taxa, using LM and SEM techniques and reported that the pollen morphological characteristics were of important characters for the taxonomic identifications of species and genera in different plant families.

\subsection{Foliar epidermal anatomy}

\subsubsection{Epidermal cells}

Great variations in epidermal cells have been observed in their number size and shape. Epidermal cells are found to be irregular in most of the species of family Amaranthaceae, Plantaginaceae, Ranunculaceae, Scrophulariaceae, Lamiaceae, Poaceae, and other species having polygonal, elongated, Isodiametric, tetragonal and wavy type of cells. Isodiametric epidermal cells are found in P. lanceolata and Phyla nodiflora (L.) (Figure 4). While tetragonal cells are present in Persicaria maculosa Gray (Figure 1) and elongated cells are found in Polypogon monspeliensis (L.) Desf and A. aspera. Polygonal cells are the character of A. plantago-aquatica and P. major (Figure 2). Different length of epidermal cells was found in the same species, the variation in cell size, large cells were observed in Arundo donax L. having irregular walls ranges from $75-115(95 \pm 20) \mu \mathrm{m}$ while minimum size was $22.5 \mu \mathrm{m}$ studied in P. lanceolata on the upper surface. The maximum length on the lower surface was examined in $A$. aspera $95 \mu \mathrm{m}$ while the minimum length $21 \mu \mathrm{m}$ on the lower surface. Based on width large cells having irregular walls and size ranges from $56.25 \mu \mathrm{m}$ in A. viridis to minimum size 6 $\mu \mathrm{m}$ Ranunculus sceleratus $\mathrm{L}$. in the adaxial surface. On the abaxial surface, the maximum sizes of the cell were $42.5 \mu \mathrm{m}$ $P$. nodiflora to a minimum of $9 \mu \mathrm{m}$ in $R$. scleratus.

\subsubsection{Stomatal morphology}

Variations among stomata were also observed in upper and lower surfaces of the leaf epidermis in all 24 species of wetland. Three types of stomata were studied, i.e. Anomocytic, Anisocytic, and Paracytic. Paracytic stomata were observed in 12 species; anomocytic type of stomata was found in 11 species remaining 2 species had anisocytic stomata. Large stomatal sizes were observed in $R$. repens and minimum size was observed in $A$. sessilis on the upper surface, while on lower surface size ranges from $49.75 \mu \mathrm{m} R$. repens to minimum (11.75) $\mu \mathrm{m}$ in R. scleratus as mentioned in Table 3. Based on width, lower and upper surfaces showed variation. The largest stomata on the upper surface are found in $R$. repens $38.6 \mu \mathrm{m}$ and smaller are found in P. lanceolata $8.25 \mu \mathrm{m}$. On the lower surface, $R$. repens $33.75 \mu \mathrm{m}$ has a maximum stomata size while the minimum size is observed in $R$. scleratus $6.75 \mu \mathrm{m}$ (Figure
5). The upper epidermal surface was observed to have a large size of stomatal pore than lower surfaces in a continuous manner. $R$. repens $41.85 \mu \mathrm{m}$ has the largest size of stomatal pore on the upper epidermis while $R$. scleratus L (11 $\mu \mathrm{m})$ has a minimum mean size of the stomatal pore. Similarly, on lower epidermis $R$. repens $36.2 \mu \mathrm{m}$ has the largest size of

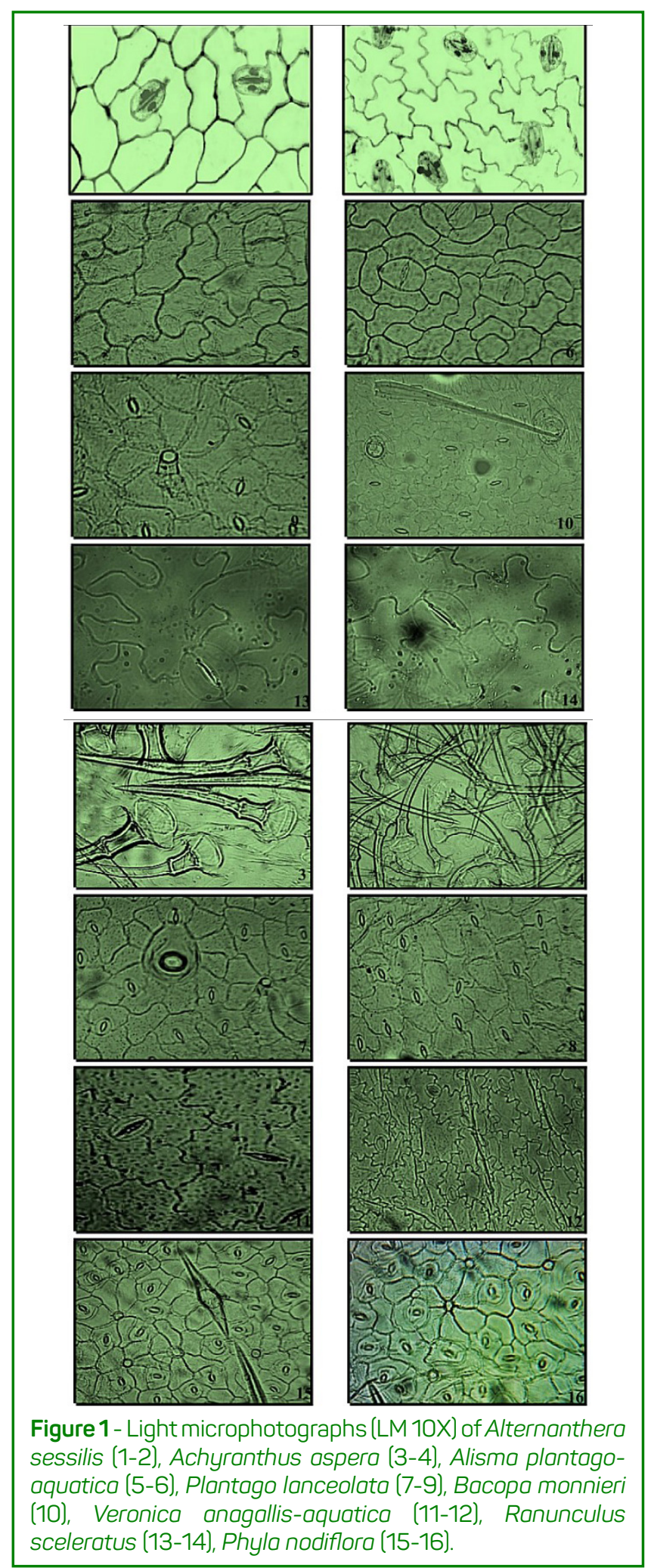


pore while $A$. viridis $8.75 \mu \mathrm{m}$ has the smallest pore size. The stomatal index of the species varied from the highest $86.5 \%$
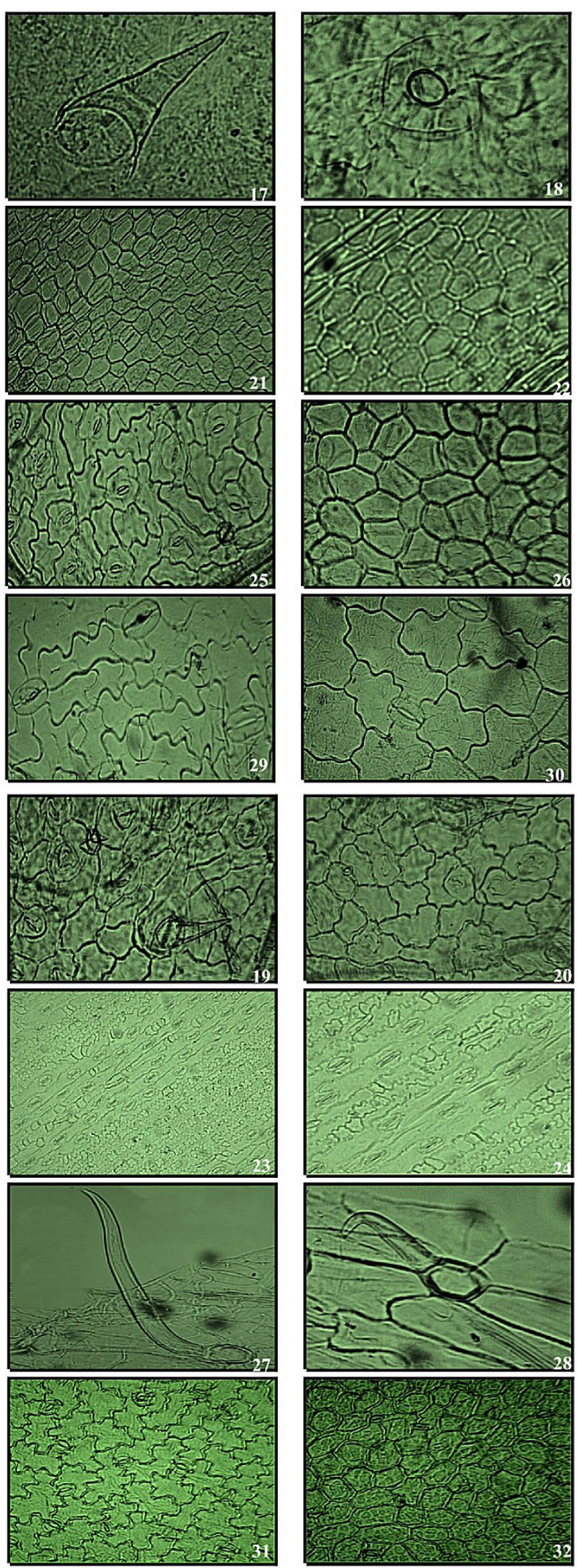

Figure 2 - Light microphotographs (LM 10X) of Solvio plebeia (17-20), Typho angustifolia (21-22), Arundo donax (23-24), Persicaria maculoso (25-28), Ranunculus muricatus (29-30), Amaranthus spinosus (31-32).
R. sceleratus to the minimum $4.6 \%$ Verbascum thapsus L. on the upper epidermis, while at the lower epidermis maximum stomatal index is $96.15 \%$ P. maculosa and minimum $3.5 \%$ Amaranthus spinosus L. (Table 3) (Figure 3).

\subsubsection{Trichomes morphology}

In 9 species, trichomes were present on both leaf surfaces. Diverse trichomes and foliar appendages i-e prickles are mostly found on the upper surface but also observe on lower surfaces. Foliar appendages were observed in A. donax, $C$. dactylon, Echinochloa colona (L.) Link, Dichanthium annulatum (Forssk.) Stapf. Barrel-shaped trichomes were found in P. major while stellate trichomes were also observed in $V$. thapsus and peltate type was present in Bacopa monnieri (L.) Wettst. Based on width largest trichome was observed in $A$. sessilis $(400 \mu \mathrm{m}),(60 \mu \mathrm{m})$ on adaxial and abaxial surfaces. Lengthwise the largest trichome size was observed in $R$. repens $(312.5 \mu \mathrm{m}),(350 \mu \mathrm{m})$ on both surfaces respectively. The foliar epidermal anatomy of $A$. aspera in our study showed that the adaxial surface of the cells is elongated while the abaxial side observed irregularly. Stomata are anomocytic on adaxial surface, and paracytic type of stomata was studied on abaxial surface, while in the study of (Ogundipe, Kadiri, 2012) the shapes of cells on both upper and lower surfaces were irregular. Stomata types showed that were observed anomocytic and paracytic two types on both surfaces. In our study we observed trichomes attenuate and bulbous base while previously study showed that trichomes were absent. In A. spinosus epidermal cells are irregular and stomata anomocytic on both adaxial and abaxial surfaces as observed by (Ogundipe, Kadiri, 2012). The foliar epidermal cells of $A$. viridis showed in the previous study that the shape of cells is irregular same in our finding, the stomata types in the study of (Ogundipe, Kadiri, 2012) was anomocytic and paracytic type in our results the stomata is Anisocytic and Anomocyic.

Foliar epidermal anatomy study of A. donax, P. monspeliensis, Phragmites karka, C. dactylon, and D. annulatum show similar stomata type paracytic types with the recent study of (Khan et al., 2017) working on family Poaceae. E. colona have tetragonal epidermal cells in our finding while (Ferreira et al., 2002; Jattisha, Sabu, 2015) studied showed that the species had wavy cells. The shape of epidermal cells in P. major in our study showed polygonal shape, while in the study of (Ahmad

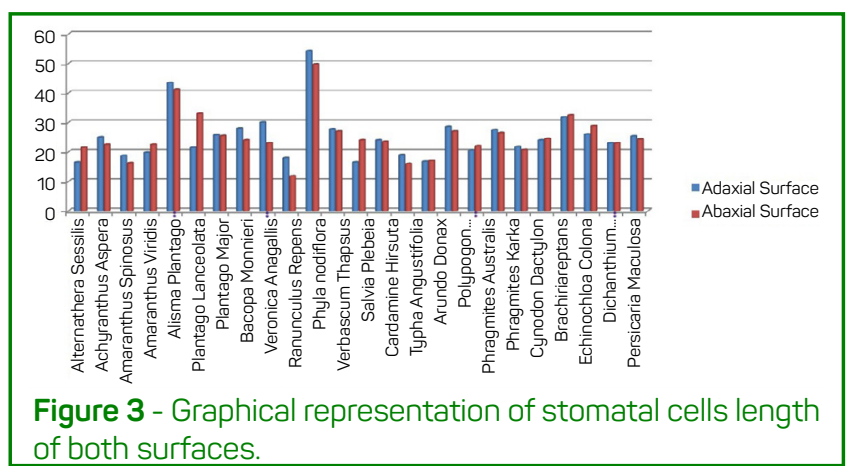




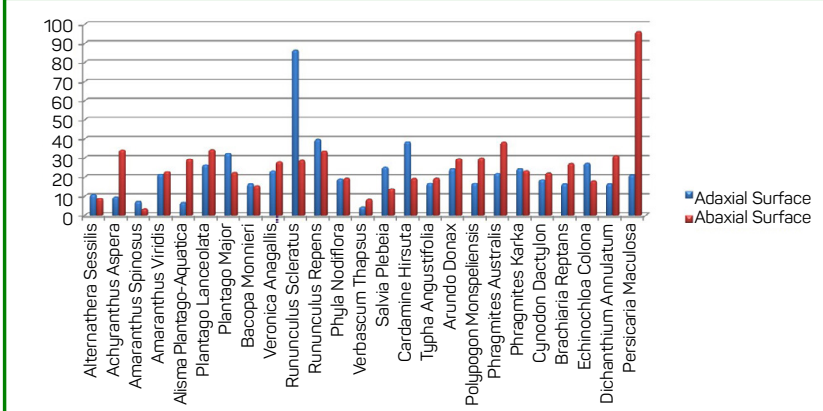

Figure 4 - Graphical representation of stomatal index of both surfaces.

et al., 2010) observed tetragonal to polygonal. In the study of (Lan et al., 2008) leaf epidermal anatomy of R. scleratus was irregular to polygonal while in our study the shape of the cells is wavy. In the present study Salvia plebeia R.Br. having anomocytic while in the study of (Dimitrova, Yurukova, 2005) the relative species had diacytic type of stomata. T. angustifolia in our research we examined round shape of epidermal cells previously (Ni et al., 2014) had also round epidermal cells. P. maculosa have anomocytic type of stomata on both surfaces while unicellular trichomes were also observed while in previous study the species had paracytic type of stomata and the trichomes were absent (Yasmin et al., 2010).

Twenty-four plant species belonging to 11 families were investigated in this work; palyno-anatomical features of these species were studied both qualitative and quantitatively. In the case of anatomical studies, clear differences were observed on the epidermal adaxial and abaxial surfaces. While in pollen morphological investigation a significant difference was observed in pollen shape, size, and diameter of the polar and equatorial axis, exine thickness, and sculpturing. The present research work was compared with the previous study reveals and confirms that the leaf epidermal light microscopy is of very important value for the identification of wetland flora. These characters have great information and possess important
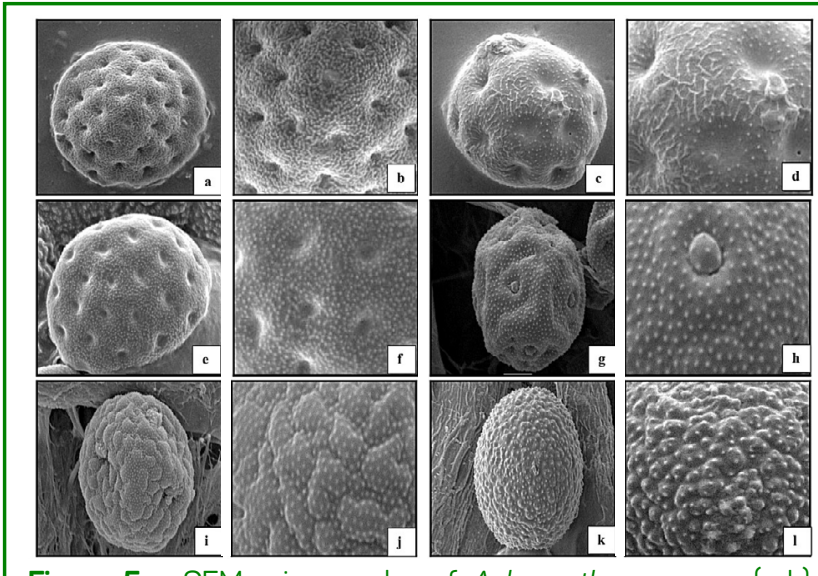

Figure 5 - SEM micrographs of Achyranthus aspera (a-b), Alternanthera sessilis (c-d), Amaranthus spinosus (e-f), Plantago lanceolata (g-h), Plantago major (i-j), Ronunculus repens. information for the correct identification of plants. In this research work, we adopted different taxonomic keys based on qualitative characters like trichomes types, epidermal cells shape, stomata types, prickles, etc. These features play a vital role in the correct identification of plants and delimitation of complex species.

\subsection{Economic importance and limitation management of wet- land weeds}

Wetland plants play important role in maintaining the nutrient balance in the water. Turbidity and excessive erosion are prevented by the diversity of wetland plants (Marwat et al., 2011). Similarly, Khan et al. (2013) documented the medicinally important 73 weed species used for the management of different disorders. These weed species are helpful for the manufacturing of different plant yields and also useful for the indigenous sellers of crude drugs of plants. The pattern of distribution, abundance, and richness to the diversity of weed species (e.g P. lanceolate, $A$. viridis, $V$. Thapsus, $D$. annulatum, $C$. dactylon) depend upon the environmental variables such as $\mathrm{pH}, \mathrm{CaCO}_{3}$, soil texture, organic matter, electrical conductivity, phosphorous and nitrogen concentration. Rafay et al. (2014) reported that in agroecosystem weeds play a significant role by giving the environmental heterogeneity and floral diversity is increase for the cropping system. Williams and Kremen (2007) described that different types of invertebrates are supported by non-crop plants because many insects for survival depend upon specific weed. On the other hand, weeds play a serious role in crop production and threat to the cultivated lands because of the use of nutrients from the soil. Weeds badly affect the yield and growth of crop plants because of nutrient demand. Weed vegetation is eliminated by the use of different control measures for example chemical approaches, cultural procedures, and biological mechanisms. In cultural operations, weeds are thrown away from the rice field (Khan et al., 2013). Identification of different weed species and farming practices plan with revised management is suggested (Iqbal et al., 2017). A. aspera is a common weed for cane crop and Jogil et al. (2019) reported that greater yield for sugarcane crop with highest height and density was produced if the crop treated with Buctril M @ $3.75 \mathrm{~kg} \mathrm{ha}^{-1}$. Similarity the judicious management is recommended for the harvesting of potential chickpea production (Hassan et al., 2010).

\subsection{Taxonomic keys based on leaf micro-morphological features}

1 + Epidermal cells irregular on both surfaces, stomata anomocytic ...................................Alternanthera sessilis

- Epidermal cell elongated on adaxial surface, irregular on abaxial, stomata paracytic on abaxial surface ........2

$2+$ Trichomes present on both surfaces with bulbous base . Achyranthus aspera

- Trichomes are absent on both surfaces.......................... 3 
3 + Epidermal cells on both surfaces irregular, stomata anomocytic on both surface ......... Amaranthus spinosus

- Epidermal cells are irregular on surface $\ldots 4$

4 + stomata anisocytic and anomocytic...Amaranthus viridis

- stomata anomocytic

$5+$ epidermal cells are polygonal on both surfaces

Alisma plantago-aquatica

- epidermal cells Isodiametric ............................................. 6

6 + stomata anomocytic ..........................Plantago lanceolata

- epidermal cells polygonal ................................................... 7

7 + stomata anisocytic ................................. Plantago major

- Stomata anomocytic on both surfaces ............................ 8

$8+$ epidermal cells on abaxial surface is polygonal

Bacopa monnieri

- Epidermal cells on both surfaces are irregular................

$9+$ trichomes are present on abaxial surface unicellular..... Veronica anagallis-aquatica

- Trichomes are absent 10

10 + Epidermal cells are wavy.................Ranunculus scleratus

- Epidermal cells are irregular .11

$11+$ Trichomes unicellular non-glandular.

Ranunculus repens

- Trichomes are absent. Phyla nodiflora

12 + Epidermal cells are isodiametric

- Epidermal cells are irregular ...12

$13+$ Trichomes are stellate 13

- Trichomes are multicellular non glandular............... 14

$14+$ Stomata are anomocytic on adaxial surface and absent on abaxial surface. Salvia plebeian

- Stomata paracytic. 15

15 + Epidermal cells are rounded ............. Typha angustifolia

- Epidermal cells Irregular. 16

$16+$ Trichomes are in prickles. Arundo donax

- Trichomes are absent 17

17 + Epidermal cells elongated......... Polypogon monspeliensis

- Epidermal cells are irregular. ...18

18 + stomata are paracytic.

- Stomata are anomocytic Phragmites australis - Epidermal cells are irregular......................................... 20

20 + Trichomes are absent.........................Phragmites karka

- Trichomes are prickles. .21

21 + Epidermal cells irregular..................... Cynodon dactylon

- Epidermal cells on adaxial surface irregular and wavy on abaxial surface. 22
$22+$ Trichomes are absent on both surfaces

Brachiaria reptans

- Trichomes are prickles on both surfaces .23

23 + Epidermal cells Irregular Echinochloa colona - Epidermal cells wavy Dichanthium annulatum

\section{Conclusions}

24 plantspeciesbelonging to 11 familieswereinvestigated in this work; palyno-anatomical features of these species were studied both qualitative and quantitatively. In the case of anatomical studies, clear differences were observed on the epidermal adaxial and abaxial surfaces. While in pollen morphological investigation a significant difference was observed in pollen shape, size, and diameter of the polar and equatorial axis, exine thickness, and sculpturing. The present research work was compared with the previous study reveals and confirms that the leaf epidermal light microscopy is of very important value for the identification of wetland weeds. These characters have great information and possess important information for the correct identification of plants. In this research work, we adopted different taxonomic keys based on qualitative characters like trichomes types, epidermal cells shape, stomata types, prickles, etc. These features play a vital role in the correct identification of plants and delimitation of complex species.

\section{Author's contributions}

MAB: primary author of this manuscript the data belongs to her. MZ: proofread the whole manuscript and helps in the collection of specimen. MA: helps in the write-up section. SK: helps in quantitative data analysis: $\mathrm{SB}$, and FU: helps in experimental work. SK: helps in plant identification.

\section{Acknowledgments}

All the authors would like to thank Central resource library (CRL), Department of Physics University of Peshawar for providing the facility of Scanning Electron microscopy. No funding is available for this project. This project is part of doctoral thesis work.

\section{Funding}

This research did not received external funding.

References

Ahmad K, Khan MA, Ahmad M, Shaheen N, Nazir A. Taxonomic diversity in epidermal cells of some sub-tropical plant species. Int J Agric Biol. 2010;12:115-8.

Ali SI. Flora of Pakistan. Islamabad: Pakistan Agricultural Research Council; 1980

Alwadie HM. Pollen morphology of six aquatic angiosperms from Saudi Arabia. Asian J Biol Sci. 2008;1:45-50. Available from: https://doi.org/10.3923/ajbs.2008.45.50
Arenas P, Scarpa GF. The consumption of Typho domingensis pers. (typhaceae) pollen among the ethnic groups of the Gran Chaco, South America. Econ Bot. 2003;57(2):181-8. Available from: https://doi.org/10.1663/0013-0001(2003)057[0181:TCOTDP]2.0.CO;2

Bahadur S, Ahmad M, Mir S, Zafar M, Sultana S, Ashfaq S et al. Identification of monocot flora using pollen features through scanning electron microscopy. Micros Res Tech. 2018;81(6): 599-613. Available from: https://doi.org/10.1002/jemt.23015 
Bhunia D, Mondal AK. Systematic analysis (morphology, anatomy and palynology) of an aquatic medicinal plant water mimosa (Neptunio oleraceo Lour.) in Eastern India. Int $J$ Life Sc Bt Pharm Res. 2012;1(2):290-319.

Borges RLB, Santos FDAR, Giulietti AM. Comparative pollen morphology and taxonomic considerations in Eriocaulaceae. Rev Palaeobot Palynol. 2009;154(1-4): 91-105. Available from: https://doi.org/10.1016/j.revpalbo.2008.12.008

Borsch T. Pollen types in the Amaranthaceae: morphology and evolutionary significance. Grana. 1998;37(3):129-42. Available from: https://doi.org/10.1080/00173139809362658

Bunawan $\mathrm{H}$, Talip N, Noor NM. Foliar anatomy and micromorphology of polygonum minus huds and their taxonomic implications. Austr $\mathrm{J}$ Crop Sci. 2011;5(2):123-7.

Butt MA, Zafar M, Ahmad M, Sultana S, Ullah F, Jan G et al. Morpho palynological study of cyperaceae from wetlands of Azad Jammu and Kashmir using SEM and LM. Microsc Res Tech. 2018;81(5):458-68. Available from: https://doi.org/10.1002/jemt.22999

Chaudhari SK, Arshad M, Mustafa G, Fatima S, Amjad MS, Yasmeen F. Foliar epidermal anatomy of grasses from Thal desert, district Khushab, Pakistan. Int J Biosci. 2014;4(8):62-70. Available from: https://doi.org/10.12692/ijb/4.8.62-70

Dimitrova I, Yurukova L. Bioindication of anthropogenic pollution with Plantago lanceolato (Plantaginaceae): metal accumulation, morphological and stomatal leaf characteristics. Phytol Balcan. 2005;11(1):89-96.

Dönmez EO, Işik S. Pollen morphology of Turkish Amaryllidaceae, Ixioliriaceae and Iridaceae. Grana. 2008;47(1):15-38. Available from: https://doi.org/10.1080/00173130701860104

El-Amier YA. Morphological studies of the pollen grains for some hydrophytes in coastal mediterranean lakes, Egypt. Egypt J Basic App Sci. 2015;2(2):132-8. Available from: https://doi.org/10.1016/j.ejbas.2015.04.001

El-Ghamery AA, Sadek AM, Abdelbar $\mathrm{OH}$. Comparative anatomical studies on some species of the genus Amaranthus (family: amaranthaceae) for the development of an identification guide. Ann Agric Sci. 2017;62(1):1-9. Available from: https://doi.org/10.1016/j.aoas.2016.11.001

Ferreira E, Procópio S, Silva E, Silva A, Rufino R. [Leaf anatomical studies in weed species: II Bidens piloso, Emilia sonchifolia, Ageratum conyzoides and Sonchus asper]. Planta Daninha. 2002;20(3):327-35. Portuguese. Available from: https://doi.org/10.1590/S0100-83582002000300001

Hassan G, Khan I, Khan MZ, Shah NH, Khan M, Liaqatullah M. Weed flora of chickenpea in district Lakki Marwat, NWFP, Pakistan. Sarhad J Agric. 2010;26(1):79-86.

Hesse M. Pollen wall ultrastructure of Araceae and Lemnaceae in relation to molecular classifications. Aliso. 2006;22(1):204-8. Available from: https://doi.org/10.5642/aliso.20062201.17

Hussain AN, Zafar M, Ahmad M, Khan R, Yaseen G, Khan MS et al. Comparative SEM and LM foliar epidermal and palyno-morphological studies of Amaranthaceae and its taxonomic implications. Microsc Res Tech. 2018;81(5):474-85. Available from: https://doi.org/10.1002/jemt.23001

lqbal M, Khan SM, Khan MA, Ahmad Z, Abbas Z, Khan SM et al. Distribution pattern and species richness of natural weeds of wheat in varying habitat conditions of district Malakand, Pakistan. Pakis J Bot. 2017;49(6):2371-82.

Jattisha PI, Sabu M. Foliar phytoliths as an aid to the identification of Paniceoe (Panicoideae: Poaceae) grasses in South India. J Plant Taxon Geogr. 2015;70(1):115-31. Available from: https://doi.org/10.1080/00837792.2015.1005908

Jogi Q, Hajano GA, Kandharo MN, Shah AN, Soomro AA, Abbasi ZA et al. Examine different weed management techniques in sugarcane (Soccharum officinarum L.). Pure Appl Biol. 2019;8(1):151-9. Available from: https://doi.org/10.19045/bspab.2018.700173

Keddy PA. Wetland ecology: principles and conservation. Cambridge: Cambridge University; 2010.

Khan R, Ahmad M, Zafar M, Ullah A. Scanning electron and light microscopy of foliar epidermal characters: a tool for plant taxonomists in the identification of grasses. Micros Res Tech. 2017;80(10):1123-40. Available from: https://doi.org/10.1002/jemt.22909

Khan RU, Mehmood S, Khan SU, Subhan M. Ethnobotanical study of common weed flora of sugarcane in district Bannu, Khyber Pakhtunkhawa Pakistan. J Med Plants Res. 2013;1(4):49-78.

Kosenko VN. Contributions to the pollen morphology and taxonomy of the Liliaceae. Grana. 1999;38(1):20-30. Available from: https://doi.org/10.1080/001731300750044672

Kubitzki K. Haloragaceae. In: Kubitzki K, editor. Flowering plants: eudicots. Berlin: Springer; 2007. p. 184-90.

Lan YL, Wu LS, Qiu BY, Gao YH, Si JP. [Houttuynia cordato analysis with RAPD markers]. J Zhejiang Forest Coll. 2008;25(3):1-5. Chinese.

Lersten NR, Curtis JD. Foliar anatomy of Polygonum (Polygonoceoe): survey of epidermal and selected internal structures. Pl Syst Evol. 1992;182(1):71-106. Available from: https://doi.org/10.1007/BF00941415

Marwat SK, Khan MA, Rehman FU, Ahmad M, Zafar M. Biodiversity and importance of floating weeds of Dara Ismail, Khan District of KPK, Pakistan. Afr J Tradit Complement Altern Med. 2011;8(5 Suppl):97-107. Available from: https://doi.org/10.4314/ajtcam.v8i5S.17

Munir M, Khan MA, Ahmed M, Seema N, Ahmed SN, Tariq K et al. Foliar epidermal anatomy of some ethnobotanically important species of wild edible fruits of northern Pakistan. J Med Plants Res. 2011;5(24):5873-80.

Nasir E, Ali S. Flora of West Pakistan 1970-1989. Karachi: Fakhri; 1970.

Nazir MS, Wahjoedi BA, Yussof AW, Abdullah MA. Eco-friendly extraction and characterization of cellulose from oil palm empty fruit bunches. BioRes. 2013;8(2):2161-72.

Ni XL, Meng Y, Zheng SS, Liu WZ. Programmed cell death during aerenchyma formation in Typho angustifolia leaves. Aqua Bot. 2014;113:8-18. Available from: https://doi.org/10.1016/j.aquabot.2013.10.004 
Ogundipe OT, Kadiri AB. Comparative foliar epidermal morphology of the West African species of Amoronthoceae Juss. Fed Repert. 2012;123(2):97-116. Available from: https://doi.org/10.1002/fedr.201100003

Özdemir A, Özdemir A, Yetisen K. Statistical comparative petiol anatomy of Solvio sp. Planta Daninha. 2016;34(3):465-74. Available from: https://doi.org/10.1590/s0100-83582016340300007

Pereira M, Martins A, Martins D, Sasso G, Silva Jr A. Effect of sethoxydim herbicide in the leaf anatomy and physiology of Brochiorio grass under water stress. Planta Daninha. 2017;35:1-8. Available from: https://doi.org/10.1590/s0100-83582017350100048

Perveen A, Qaiser M. Pollen flora of Pakistan-LXIX. Poaceae. Pak J Bot 2012;44(2):747-56

Rafique M, Basharat M, Saeed RA, Rahamn SU. Effect of geology and altitude on ambient outdoor gamma dose rates in district Poonch, Azad Kashmir. Carpath J Earth Envir Sci. 2013;8(4):165-73.

Rafay M, Hussain T, Ruby T, Rehman F, Ahmad I, Abdullah M. Role of weeds in creating agro-ecological stability. Pakistan $J$ Agric Sci. 2014;51(3):531-8.

Sardar AA. A contribution to the morphological and ethnopharmacological studies of the pollen grains of wetland plants of punjab, Pakistan [thesis]. Lahore: University Lahore; 2008

Santos LDT, Meira RMSA, Santos IC, Ferreira FA. [Effect of glyphosate on the morpho-anatomy of leaves and stems of $C$. diffuso and $C$. benghalensis]. Planta Daninha. 2004;22(1):1-107. Portuguese. Available from: https://doi.org/10.1590/S0100-83582004000100013
Sufyan M, Badshah I, Ahmad M, Zafar M, Bahadur S, Rashid N. Identification of medicinally used flora using pollen features imaged in the scanning electron microscopy in the lower Margalla Hills Islamabad Pakistan. Microsc Microanal. 2018;24(3):292-9. Available from: https://doi.org/10.1017/S1431927618000326

Uka C, Okeke C, Awomukwu D, Aziagba B, Muoka R. Taxonomic significance of foliar epidermis of some phyllanthus species in south eastern Nigeria. IOSR J Pharm Biol Sci. 2014;9(4):1-6.

Ullah F, Zafar M, Ahmad M, Dilbar S, Shah SN, Sohail A, Tariq A. Pollen morphology of subfamily Caryophylloideae (Caryophyllaceae) and its taxonomic significance. Microsc Res Tech. 2018;81(7):704-15. Available from: https://doi.org/10.1002/jemt.23026

Waly NM. Anatomical and statistical analysis of six parasitic loranthaceae species. Am J Res Comm. 2013;1(4):317-32.

Wang YH, Lu L, Fritsch PW, Wang H, Wang YH, Li DZ. Leaf epidermal character variation and evolution in Goultherieoe (Ericaceae). Bot J Linn Soc. 2015;178(4):686-710. Available from: https://doi.org/10.1111/boj.12296

Wetzel M, Sylvestre LDS, Barros C, Vieira R. Vegetative anatomy of Asplenioceoe newmon from brazilian atlantic rainforest and its application in taxonomy. Flora. 2017;233:118-26. Available from: https://doi.org/10.1016/j.flora.2017.05.010

Williams NM, Kremen C. Resource distributions among habitats determine solitary bee offspring production in a mosaic landscape. Ecol Applic. 2007;17(3):910-21. Available from: https://doi.org/10.1890/06-0269

Yasmin G, Khan MA, Shaheen N, Hayat MQ. Taxonomic significance of leaf epidermal anatomy of selected Persicario Mill. species of family Polygonaceoe from Pakistan. Afr J Biotechnol. 2010;9(25):3759-68. 